Позняковська Н. М. [1; ORCID ID: 0000-0003-4016-8935], к.е.н., доцент, Демчук М. С. ${ }^{[2]}$, бухгалтер

${ }^{1}$ Національний університет водного господарства та природокористування, м. Рівне

${ }^{2}$ Товариство з обмеженою відповідальністю «ЄВРОМОНТАЖЗАХІД», м. Рівне

\title{
ФІНАНСОВА ЗВІТНІСТЬ МАЛОГО І СЕРЕДНЬОГО БІЗНЕСУ: УКРАЇНА ТА СВІТОВИЙ ДОСВІД
}

У статті розглянуто підходи до фінансової звітності малих підприємств на світовому і національному рівнях. Надано рекомендації використання в Україні Міжнародних стандартів фінансової звітності (МСФЗ) для малих і середніх підприємств. Вказано особливості розкриття фінансової інформації у звітності суб'єктів малого бізнесу країн ЄС. Для покращення якісних характеристик фінансової звітності малих підприємств пропонуються зміни до їх структури та складу.

Ключові слова: малі підприємства; середні підприємства; фінансова звітність; спрощена фінансова звітність; Міжнародні стандарти фінансової звітності для малих і середніх підприємств; Директиви ЄС.

Постановка проблеми. Чинна Угода про асоціацію між Україною та Європейським Союзом від 2014 року передбачає в рамках своєї імплементації заходи з удосконалення бухгалтерського обліку. Не зважаючи на дослідження трансформації вітчизняної звітності до європейських стандартів, суттєвого перегляду звітності суб'єктів малого бізнесу не сталось. Суб'єкти малого та мікропідприємництва становлять особливий сектор економіки будь-якої країни, оскільки виступають важливим фактором соціальної стабільності та економічного зростання. Кращою світовою практикою пропонується застосування для малих i середніх підприємств окремого Міжнародного стандарту фінансової звітності (далі - МСФЗ для МСП) [1], який визначає мету, принципи, склад фінансової звітності для малого бізнесу.

В Україні великі компанії, а також окремі суб'єкти господарювання, визначені основним бухгалтерським законом [2], мають досвід підготовки фінансової звітності за МСФЗ. Проте реформування бухгалтерського обліку, задеклароване Стратегією застосування Міжнародних стандартів фінансової звітності в Україні [3], стосується всіх суб'єктів господарювання, малих підприємств 
зокрема. Отже, потрібно визначити диференційовані підходи до вимог підготовки українськими підприємствами фінансових звітів за національними чи міжнародними стандартами.

Основною рушійною силою економіки в країнах з розвинутою економікою $€$ малий бізнес, який відіграє важливу роль у розвитку ринкових відносин. Однак, в умовах світової кризи, викликаної пандемією, введенням карантинних умов і обмежень, загостренням питань безпеки, зокрема екологічної, фінансової, інформаційної, малий бізнес повинен стати одним 3 стратегічних напрямів економічного розвитку країни. Малі підприємства досить гнучкі, здатні адаптовуватись до нових умов, проте водночас $€$ більш вразливими, а тому потребують якісного, креативного менеджменту. Інформаційне забезпечення управління малим підприємством покладене на облікову систему. Правильна організація облікової системи, достовірність фінансової звітності дасть змогу підготувати повну інформацію задля прийняття ефективних управлінських рішень.

Аналіз останніх досліджень та публікацій. Проблемам вдосконалення бухгалтерського обліку та фінансової звітності присвячено багато досліджень і публікацій вчених і практиків: П. Атамаса, К. Безверхого, Ф. Бутинця, Ю. Вериги, Т. Гоголь, С. Голова, Ю. Кузьминського, М. Кужельного, В. Лень, Л. Ловінської, Н. Малюги, В. Палія, В. Пархоменка, Я. Соколова, В. Сопко, В. Швеця, інших. Однак, залишаються мало досліджуваними склад та особливості складання спрощеної фінансової звітності.

Є.П.Гнатенко, І. В. Соболева [4], порівнюючи фінансову звітність суб'єктів малого та мікропідприємництва України та країн ЄC, обговорюють можливості запозичення позитивного досвіду зарубіжних країн для України.

Методичні підходи до формування показників фінансової звітності підприємств малого бізнесу з урахуванням інформаційних потреб різних категорій користувачів на розкриття фінансової інформації розглядались у працях Т. А. Гоголь [5].

Проведене Н.В.Хоча [6] дослідження Фінансового звіту суб'єктів малого підприємництва (далі - СМП) та Спрощеного фінансового звіту СМП, дало змогу запропонувати зміни до їх складу та структури шляхом введення основних і додаткових статей до форм фінансової звітності малих підприємств.

К. В. Безверхим [7, С. 42] описана методика заповнення Спрощеного фінансового звіту СМП. 
Порівняльна характеристика системи звітності Польщі та України у секторі МСП в рамках імплементації угоди України з ЄС представлена у роботах І. С. Ковової [8].

Спрощену форму організації обліку малих підприємств вивчають Т.А. Гоголь та Н.І. Ніпорко [9], питання обліку на малих підприємствах в контексті оподаткування містяться у працях П. Й. Атамас, С. І. Дробязко, Т. М. Козир та С. Б. Холод [10].

Проте, залишаються дискусійними питання застосування малими та середніми підприємствами тих чи інших положень кращої світової практики розкриття фінансової інформації у звітності.

Метою статті $€$ дослідження підходів до складання малими і середніми підприємствами фінансової звітності за Міжнародними стандартами та законодавством ЄС і надання рекомендацій щодо вдосконалення їх обліку та фінансової звітності.

Виклад основного матеріалу. У сучасних економічних умовах малі та середні підприємства відіграють вирішальну роль у забезпеченні зайнятості населення, виступають важливим фактором соціальної стабільності та економічного зростання. Проте особливістю функціонування малого бізнесу на ринку $\epsilon$ значна залежність від ризиків та негативних коливань в політиці та економіці. Аргументом на користь державного регулювання малих та середніх підприємств виступає підтримка у доступі до кредитних коштів, запровадження інноваційних та інвестиційних проєктів, надання грантів, субсидій, пільг, зменшення адміністративного тиску та податкового навантаження. Окремим важливим важелем впливу на малий бізнес є застосування спрощеної системи оподаткування, обліку та звітності.

Як і в більшості країн світу, в Україні малий бізнес займає вагому частку. За офіційними даними [11], кількість малих підприємств в Україні у 2019 році становила 362,33 тис. або 18,66\% від загальної сукупності підприємств, з них найбільшу долю мають мікропідприємства (86,49\%). Найбільша частка малих підприємств зосереджена у торгівлі (27\%), сільському господарстві (13\%), промисловості (12\%). Водночас найменша - в освіті, мистецтві, охороні здоров'я, фінансовій та страховій діяльності - лише по 1\%. На малих підприємствах кількість зайнятих працівників складає 1746,6 тис. осіб або 27,3\% від загальної сукупності у 2019 році та 27,5\% у 2018 р. Середні та малі підприємства у 2019 році виробили продукції, товарів, робіт, послуг обсягом 64,1\% від загального показника вітчизняних суб'єктів господарювання [11]. 
За даними Європейської Комісії, малі та середні підприємства (МСП) складають близько 90\% від усіх підприємств у ЄС. Україні необхідно збільшити підтримку малих та мікропідприємств, враховуючи руйнівні наслідки пандемії для малого і середнього бізнесу.

32018 року в Україні запроваджена нова класифікація підприємств на мікропідприємства, малі, середні та великі (табл. 1). Відповідно до Директиви ЄС 34/2013/ЄС [12] Законом України «Про бухгалтерський облік і фінансову звітність в Україні» [2] змінено критерії віднесення суб'єктів господарювання. Ними стали балансова вартість активів та чистий дохід від реалізації продукції (товарів, робіт, послуг).

Таблиця 1

Класифікація підприємств відповідно до Закону України

«Про бухгалтерський облік та фінансову звітність в Україні»

\begin{tabular}{|c|c|c|c|c|c|}
\hline \multirow{2}{*}{$\begin{array}{l}\text { № } \\
3 / \text { }\end{array}$} & \multirow{2}{*}{ Показник } & \multicolumn{4}{|c|}{ Види підприємств } \\
\hline & & Мікропідприємство & Мале & Середнє & Велике \\
\hline 1. & $\begin{array}{c}\text { Балансова } \\
\text { вартість } \\
\text { активів }\end{array}$ & до 350 тис. євро & $\begin{array}{l}\text { до } 4 \\
\text { млн } \\
\text { євро }\end{array}$ & $\begin{array}{l}\text { до } 20 \\
\text { млн } \\
\text { євро }\end{array}$ & $\begin{array}{c}\text { понад } \\
20 \text { млн } \\
\epsilon \text { вро }\end{array}$ \\
\hline 2. & $\begin{array}{c}\text { Чистий } \\
\text { дохід від } \\
\text { реалізації } \\
\text { продукції } \\
\text { (робіт, } \\
\text { послуг) }\end{array}$ & до 700 тис. євро & $\begin{array}{l}\text { до } 8 \\
\text { млн } \\
\text { євро }\end{array}$ & $\begin{array}{l}\text { до } 40 \\
\text { млн } \\
\text { євро }\end{array}$ & $\begin{array}{c}\text { понад } \\
40 \text { млн } \\
\epsilon в р о\end{array}$ \\
\hline 3. & $\begin{array}{c}\text { Середня } \\
\text { кількість } \\
\text { працівників }\end{array}$ & до 10 осіб & $\begin{array}{c}\text { до } 50 \\
\text { осіб }\end{array}$ & $\begin{array}{c}\text { до } 250 \\
\text { осіб }\end{array}$ & $\begin{array}{c}\text { понад } \\
250 \\
\text { осіб }\end{array}$ \\
\hline
\end{tabular}

Фінансова звітність малих підприємств в Україні регулюється Національним положенням (стандартом) бухгалтерського обліку 1 (далі - НП(С)БО 1) «Загальні вимоги до фінансової звітності» [13], який визначив склад повного комплекту фінансової звітності, та НП(С)БО 25 «Спрощена фінансова звітність» [14], що встановив порядок, зміст і форму спрощеного фінансового звіту малих підприємств. Згідно з ч. 3 ст. 11 Закону № 996 [2], а з 23.07.2019 р. i згідно з п. 2 розділу І НП(С)БО 25 [15] є 5 груп підприємств, які мають право подавати скорочену за показниками фінансову звітність у складі Балансу та Звіту про фінансові результати. Це:

- малі підприємства;

- мікропідприємства; 
- представництва іноземних суб'єктів господарювання;

- непідприємницькі товариства;

- підприємства, яким надано право на ведення спрощеного обліку доходів і витрат (платники єдиного податку третьої групи.

Однак, скорочену фінансову звітність мають право подавати тільки ті з вищезазначених підприємств, які не застосовують Міжнародні стандарти фінансової звітності.

Відповідно до п. 2 розд. II НП(С)БО 1 мікропідприємства та малі підприємства можуть самостійно визначати доцільність складання фінансової звітності - підприємство вирішує, який комплект звітності подавати: скорочену фінансову звітність відповідно до НП(С)БО 25 чи повний комплект фінансової звітності (абзац перший п. 1 розд. II $\mathrm{H} П(\mathrm{C}) Б О 1)$.

Малі підприємства також можуть складати фінансову звітність згідно з МСФЗ для МСП. Це підприємства, які зобов'язані застосовувати Міжнародні стандарти фінансової звітності відповідно до законодавства, а також ті підприємства, які прийняли таке рішення самостійно. Так, МСФЗ для МСП призначений для застосування малими та середніми підприємствами, які не $\epsilon$ підзвітними громадськості та оприлюднюють фінансові звіти загального призначення для зовнішніх користувачів [1]. МСФЗ для МСП розроблені на підставі повної версії МСФЗ, але є самостійним продуктом, який враховує потреби користувачів та співвідношення користі і вигід від використання інформації. МСФЗ для МСП по суті передбачається застосовувати усіма підприємствами, що складають фінансові звіти загального призначення, і не включені до лістингу. За різними оцінками вважається, що кількість суб'єктів, які б могли застосовувати цей стандарт у світі від 65 до 95\% компаній [1].

У табл. 2 порівняємо форми та особливості складання і подання фінансової звітності малих і мікропідприємств відповідно до вимог національних та Міжнародних стандартів, а також законодавства країн ЄС. Практика складання малими підприємствами фінансової звітності за національними, Міжнародними стандартами та Директивою ЄС відрізняється. В Україні малі підприємства подають фінансову звітність у спрощеному комплекті за НП(С)БО 25 або у повному за НП(С)БО 1, також для підприємств, які становлять суспільний інтерес обов'язковим є складання звітності за МСФЗ.

Згідно з Директивою ЄС малі підприємства складають Баланс (скорочену форму), Звіт про прибутки та збитки (скорочену форму) та Примітки (склад обмежено). Директивою не забороняється використання в країнах ЄС МСФЗ для МСП. 
Порівняння положень національних та Міжнародних стандартів фінансової звітності малих підприємств, законодавства країн ЄС

\begin{tabular}{|c|c|c|c|c|c|}
\hline № & $\begin{array}{c}\text { НП(С)БО } 25 \\
\text { «Спрощена } \\
\text { фінансова звітність» } \\
\text { в Україні [15] }\end{array}$ & МСФЗ для МСП [1] & $\begin{array}{c}\text { Директива } \\
\text { 2013/34/ЄС (для } \\
\text { мікро та малих } \\
\text { підприємств) [12] }\end{array}$ & $\begin{array}{c}\text { Закон «Про } \\
\text { бухгалтерський } \\
\text { облік» в Польщі (для } \\
\text { мікро та малих } \\
\text { підприємств) [13] }\end{array}$ & $\begin{array}{c}\text { Генеральний план } \\
\text { бухгалтерського } \\
\text { обліку для МСп } \\
\text { Іспанії [4] }\end{array}$ \\
\hline 1 & $\begin{array}{c}\text { Встановлена форма, } \\
\text { зміст та порядок } \\
\text { заповнення } \\
\text { фінансової звітності } \\
\text { СмП }\end{array}$ & $\begin{array}{c}\text { Визначає повний } \\
\text { перелік } \\
\text { методологічних } \\
\text { основ обліку і } \\
\text { складання звітності }\end{array}$ & $\begin{array}{c}\text { Містить заходи щодо } \\
\text { визначення } \\
\text { категорій } \\
\text { підприємств для } \\
\text { складання фінан- } \\
\text { сової, консолідо- } \\
\text { ваної звітності }\end{array}$ & $\begin{array}{c}\text { Встановлює правила } \\
\text { ведення обліку, } \\
\text { складання звітності, } \\
\text { ї̈ оприлюднення, } \\
\text { аудит та надання } \\
\text { бухгалтерських } \\
\text { послу }\end{array}$ & $\begin{array}{c}\text { Для адаптації до } \\
\text { європейських } \\
\text { стандартів обліку і } \\
\text { вимог Директив ЄС з } \\
\text { урахуванням } \\
\text { особливостей МСП }\end{array}$ \\
\hline 2 & $\begin{array}{c}\text { Баланс форма № 1- } \\
\text { м; Звіт про фінансові } \\
\text { результати форма } \\
\text { № 2-м або Баланс } \\
\text { форма № 1-мс, Звіт } \\
\text { про фінансові } \\
\text { результати форма } \\
\text { № 2-мс }\end{array}$ & $\begin{array}{c}\text { Звіт про фінансовий } \\
\text { стан; єдиний Звіт } \\
\text { про сукупний дохід } \\
\text { за звітний період } \\
\text { або окремо Звіт про } \\
\text { прибутки та збитки і } \\
\text { Звіт про сукупний } \\
\text { дохід; Звіт про зміни } \\
\text { у власному капіталі; } \\
\text { Звіт про рух } \\
\text { грошових коштів; } \\
\text { Примітки. }\end{array}$ & $\begin{array}{c}\text { Баланс (скорочена } \\
\text { форма); Звіт про } \\
\text { прибутки та збитки } \\
\text { (скорочена форма); } \\
\text { Приміток (склад } \\
\text { обмежено) }\end{array}$ & $\begin{array}{c}\text { Баланс; Звіт про } \\
\text { прибутки та збитки } \\
\text { за умови розкриття } \\
\text { необхідної } \\
\text { інформації у } \\
\text { вступній частині до } \\
\text { фінансової звітності } \\
\text { (розділ «Загальна } \\
\text { інформація» до } \\
\text { Балансу) примітки } \\
\text { не складаються }\end{array}$ & $\begin{array}{c}\text { Баланс; Звіт про } \\
\text { прибутки і збитки; } \\
\text { Звіт про зміни у } \\
\text { капіталі; Примітки }\end{array}$ \\
\hline
\end{tabular}


Особливістю МСФЗ для МСП $є$ те, що стандарти не передбачають скороченої форми складання фінансової звітності, як вітчизняний НП(С)БО 25 «Спрощена фінансова звітність». На відміну від звітності малих підприємств України, форми якої затверджені на законодавчому рівні, МСФЗ для МСП не містить форм звітів, лише рекомендації щодо розкриття інформації у фінансових звітах.

Аналіз Балансу і Звіт про прибутки та збитки/ Звіту про фінансові результати вітчизняних підприємств та країн ЄС свідчить, що суттєвих розбіжностей у формі документів немає (табл. 3,4 ).

Таблиця 3

Порівняння горизонтального Балансу підприємств країн ЄС та балансу малих підприємств в Україні

\begin{tabular}{|c|c|}
\hline $\begin{array}{c}\text { Горизонтальний баланс } \\
\text { (додаток III Директиви } \\
\text { 34/2013€С) }\end{array}$ & $\begin{array}{c}\text { Форма № 1-м «Баланс» в Україні } \\
\text { (НП(С)БО 25) }\end{array}$ \\
\hline \multicolumn{2}{|r|}{ АКТИВ } \\
\hline $\begin{array}{l}\text { А. Підписний } \\
\text { неоплачений капітал }\end{array}$ & - \\
\hline В. Організаційні витрати & - \\
\hline С. Основні засоби & І. Необоротні активи \\
\hline І. Нематеріальні активи & Нематеріальні активи \\
\hline II. Матеріальні активи & $\begin{array}{l}\text { Незавершені капітальні інвестиції. Основні } \\
\text { засоби. Довгострокові біологічні активи }\end{array}$ \\
\hline III. Фінансові активи & Довгострокові фінансові інвестиції \\
\hline- & Інші необоротні активи \\
\hline D. Оборотні активи & II. Оборотні активи \\
\hline І. Запаси & Запаси \\
\hline $\begin{array}{l}\text { II. Дебіторська } \\
\text { заборгованість }\end{array}$ & $\begin{array}{l}\text { Дебіторська заборгованість (за статтями). } \\
\text { Витрати майбутніх періодів }\end{array}$ \\
\hline III. Інвестиції & Поточні фінансові інвестиції \\
\hline $\begin{array}{l}\text { IV. Готівкові кошти в } \\
\text { банку та їх рух }\end{array}$ & Гроші та їх еквіваленти \\
\hline- & Інші оборотні активи \\
\hline- & $\begin{array}{l}\text { III. Необоротні активи утримувані для } \\
\text { продажу та групи вибуття }\end{array}$ \\
\hline \multicolumn{2}{|r|}{ ПАСИВ } \\
\hline А. Капітал і резерви & І. Власний капітал \\
\hline І. Підписний капітал & $\begin{array}{l}\text { Зареєстрований (пайовий капітал). } \\
\text { Неоплачений капітал }\end{array}$ \\
\hline $\begin{array}{l}\text { II. Рахунок емісійного } \\
\text { доходу }\end{array}$ & Додатковий капітал \\
\hline III. Резерв переоцінки & - \\
\hline
\end{tabular}


продовження табл. 3

\begin{tabular}{|c|c|}
\hline IV. Резерви (обов'язкові) & Резервний капітал \\
\hline $\begin{array}{l}\text { V. Прибуток або збиток } \\
\text { перенесений на } \\
\text { наступний період }\end{array}$ & \multirow{2}{*}{$\begin{array}{c}\text { Нерозподілений прибуток (непокритий } \\
\text { збиток) }\end{array}$} \\
\hline $\begin{array}{l}\text { VI. Прибуток або збиток за } \\
\text { фінансовий рік }\end{array}$ & \\
\hline В. Резерви & - \\
\hline \multirow[t]{2}{*}{$\begin{array}{l}\text { С. Кредиторська } \\
\text { заборгованість }\end{array}$} & $\begin{array}{l}\text { II. Довгострокові зобов'язання та } \\
\text { забезпечення. }\end{array}$ \\
\hline & III. Поточні зобов'язання та забезпечення \\
\hline- & $\begin{array}{l}\text { IV. Зобов'язання, пов'язані з необоротними } \\
\text { активами утримуваними для продажу і } \\
\text { групами вибуття }\end{array}$ \\
\hline
\end{tabular}

Таблиця 4

Порівняння Звіту про прибутки і збитки за Директивою ЄС та звіту про фінансові результати (ф. № 2-м) за НП(С)БО 25

\begin{tabular}{|c|c|}
\hline $\begin{array}{c}\text { Звіт про прибутки і збитки (додаток VI } \\
\text { Директиви 34/2013ЄС) }\end{array}$ & $\begin{array}{c}\text { Форма № 2-м «Звіт про } \\
\text { фінансові результати» в } \\
\text { Україні (НП(С)БО 25) }\end{array}$ \\
\hline Чистий оборот & $\begin{array}{c}\text { Чистий дохід від реалізації } \\
\text { продукції, товарів, робіт, } \\
\text { послуг }\end{array}$ \\
\hline $\begin{array}{c}\text { Собівартість реалізованої продукції } \\
\text { включаючи коригування вартості }\end{array}$ & $\begin{array}{c}\text { Собівартість реалізованої } \\
\text { продукції товарів, робіт, } \\
\text { послуг } \\
\end{array}$ \\
\hline Валовий прибуток або збиток & $\begin{array}{c}\text { Фінансовий результат до } \\
\text { оподаткування }\end{array}$ \\
\hline Витрати на реалізацію & \multirow{2}{*}{ Інші операційні витрати } \\
\hline Адміністративні витрати & \\
\hline Інші операційні доходи & Інші операційні доходи \\
\hline Доходи від участі & \multirow{3}{*}{ Інші доходи } \\
\hline Доходи від інших інвестицій і позик & \\
\hline Інші відсотки до одержання & \\
\hline $\begin{array}{c}\text { Коригування вартості фінансових коштів та } \\
\text { інвестицій, що використовуються в якості } \\
\text { оборотних активів }\end{array}$ & Інші операційні витрати \\
\hline Відсотки до виплат і аналогічні витрати & Інші витрати \\
\hline $\begin{array}{c}\text { Податок на прибуток або збиток від } \\
\text { звичайної діяльності }\end{array}$ & Податок на прибуток \\
\hline $\begin{array}{l}\text { Прибуток або збиток від звичайної } \\
\text { діяльності після оподаткування }\end{array}$ & Чистий прибуток або збиток \\
\hline $\begin{array}{c}\text { Інші податки, не відображені в попередніх } \\
\text { статтях }\end{array}$ & - \\
\hline Прибуток або збитки за фінансовий рік & Чистий прибуток або збиток \\
\hline
\end{tabular}


Однак, методологія формування статей фінансових звітів підприємств європейських країн та в Україні суттєво відрізняється. Це стосується застосування принципів підготовки фінансових звітів, визнання i оцінки таких їх основних елементів, як активів, зобов'язань, капіталу, доходів і витрат.

Польща як держава-член ЄC у сфері бухгалтерського обліку регулюється Регламентом ЄC 1606/2002 та Директивою ЄC 2013/34/€С, яка встановлюе основні вимоги до підготовки фінансової звітності, а також вимагає відповідності МСФЗ, які схвалені Європейською Комісією. Положення Директиви були введені поступово у бухгалтерські норми за польським Законом «Про бухгалтерський облік» [15]. Польські компанії, які не застосовують Міжнародні стандарти, зокрема, малі та середні підприємства, використовують національні стандарти бухгалтерського обліку. МСФЗ для МСП не були прийняті до використання в Польщі.

В Іспанії, поряд із загальною системою бухгалтерського обліку i звітності, прийнято Генеральний план бухгалтерського обліку для малих і середніх підприємств 1515/2007, яким передбачено спрощений формат фінансової звітності, встановлено спільний критерій визнання, окремий план рахунків та форми фінансової звітності [4]. Облік і звітність суб'єктів мікропідприємництва має певні спрощення, але суттєво не відрізняються від фінансової звітності малих і середніх підприємств, які складають усі форми звітності.

Отже, національні та міжнародні нормативні документи 3 регулювання обліку і звітності для МСБ орієнтовані на спрощення складання та подання фінансової звітності. Водночас, існують значні відмінності у критеріях визнання суб'єктів мікро та малого підприємництва, на які поширюється право складати спрощену звітність; склад та форми спрощеної фінансової звітності, обсяг інформації, який вони охоплюють. Зазначимо, що МСФЗ для МСП охоплює більше коло користувачів, включаючи середні підприємства.

Висновки. За Директивою 34/2013/ЄС мікро-, малі та середні підприємства складають скорочений баланс та скорочений звіт про прибутки та збитки, примітки. Дана Директива не забороняє використання МСФЗ для МСП в країнах ЄС. В Україні облік і звітність здійснюється за національними або Міжнародними стандартами на вибір підприємства, за винятком, коли застосування МФЗ $\epsilon$ обов'язковим відповідно до законодавства.

Вважаємо доцільним гармонізувати національне законодавство 
Серія «Економічні науки»

Випуск 4(92) 2020 р.

з МСФЗ для МСП. МСФЗ для МСП $є$ більш детальним та конкретизованим ніж НП(С)БО 25, стандарт не тільки містить положення щодо подання фінансової звітності, а й роз'яснює важливі аспекти бухгалтерського обліку для малих та середніх підприємств.

Для покращення якісних характеристик та інформативності фінансової звітності рекомендуємо надавати примітки у складі фінансової звітності малих підприємств. Необхідно визначити у примітках статті, які $€$ обов'язковими для всіх суб'єктів, та такі, які можуть варіюватись залежно від специфіки та обсягів діяльності підприємства. Слід відображати додаткові статті, якщо інформація $\epsilon$ суттєвою.

1. International Financial Reporting Standard for Small and Medium-sized Entities (IFRS for SMEs). URL: https://www.ifrs.org/issued-standards/ifrs-for-smes/ (дата звернення: 08.12.2020). 2. Про внесення змін до Закону України «Про бухгалтерський облік та фінансову звітність в Україні» щодо удосконалення деяких положень» : Закон України від 05.10.2017 р. №2164-VIII. URL: http://zakon5.rada.gov.ua/laws/show/2164-19. (дата звернення: 08.12.2020). 3. Про продовження терміну виконання заходів із застосування міжнародних стандартів фінансової звітності в Україні» : розпорядження Кабінету Міністрів України від 17 березня 2011 p. № 2052-p. Міністерство фінансів України. URL: http://www.minfin.gov.ua/ (дата звернення: 08.12.2020). 4. Гнатенко Є. П., Соболева І.В. Порівняння фінансової звітності суб'єктів малого та мікропідприємництва України та країн ЄС. Молодий вчений. 2017. № 5. С. 537-541. 5. Гоголь Т. А. Обліково-аналітичне забезпечення управління підприємств малого бізнесу : монографія. Чернігів : Видавець Лозовий В.М. 2014. 384 с. 6. Хоча Н. В. Перспективи вдосконалення форм фінансової звітності малих підприємств. Бізнес Інформ. 2018. № 3. С. 259-263. 7. Безверхий К. Порядок складання спрощеного фінансового звіту суб'єкта малого підприємництва. Бухгалтерський облік $і$ аудит. 2016. № 11-12. С. 40-50. 8. Гармонізація бухгалтерського обліку та оподаткування на підприємствах України в контексті нормативів ЄС : монографія / О. І. Малишкін, К. В. Безверхий, І. С. Ковова, С. М. Семенова, С. М. Шуляренко, В. П. Карєв ; за наук. ред. О. І. Малишкіна. Державний університет інфраструктури та технологій. Київ: ДУІТ, 2018. 416 с. 9. Гоголь Т. А., Ніпорко Н. І. Аналіз нормативно-правової бази з регулювання бухгалтерського обліку суб'єктів малого бізнесу. Економічні науки. Cер. Облік i фінанси. 2012. Вип. 9 (1). С. 208-216. URL: http://nbuv.gov.ua/UJRN/ecnof_2012_9\%281\%29_31 (дата звернення: 08.12.2020). 10. Дробязко С.І., Козир Т. М., Холод С. Б. Облік та оподаткування підприємств малого бізнесу : навч. посіб. / за заг. ред. П. Й. Атамаса. К. : Центр учбової літератури, 2012. 416 c. 11. URL: http://www.ukrstat.gov.ua/ (дата звернення: 08.12.2020). 12. Directive 2013/34/EU of the European Parliament and of the Council of 26 June 2013 on the annual financial statements, consolidated financial statements and related reports of certain types of undertakings, amending Directive 2006/43/EC of the European Parliament and of the Council and repealing Council Directives 78/660/EEC and 83/349/EEC/ URL: http://eur-lex.europa.eu/ (дата звернення: 08.12.2020). 13. Костюченко В. М., Кравчук А. О. Досвід Польщі у євроконвергенції бухгалтерського обліку та аудиту. Глобальні та національні проблеми економіки. 
Вип. 20. 2017. С. 971-976. URL: http://global-national.in.ua/archive/20-2017/197.pdf (дата звернення: 08.12.2020). 14. Національне положення (стандарт) бухгалтерського обліку 1 «Загальні вимоги до фінансової звітності» Затв. Міністерством фінансів України від 7.02.2013 р. № 73. URL: www.mimfin. gov.ua (дата звернення: 08.12.2020). 15. Положення (стандарт) бухгалтерського обліку 25 «Спрощена фінансова звітність»: наказ Міністерства фінансів України від 25 лютого 2000 року. URL: www.mimfin. gov.ua (дата звернення: 08.12.2020).

\section{REFERENCES:}

1. International Financial Reporting Standard for Small and Medium-sized Entities (IFRS for SMEs). URL: https://www.ifrs.org/issued-standards/ifrs-for-smes/ (data zvernennia: 08.12.2020). 2. Pro vnesennia zmin do Zakonu Ukrainy «Pro bukhhalterskyi oblik ta finansovu zvitnist v Ukraini» shchodo udoskonalennia deiakykh polozhen» : Zakon Ukrainy vid 05.10 .2017 r. № 2164-VIII. URL: http://zakon5.rada.gov.ua/laws/show/2164-19. (data zvernennia: 08.12.2020). 3. Pro prodovzhennia terminu vykonannia zakhodiv iz zastosuvannia mizhnarodnykh standartiv finansovoi zvitnosti v Ukraini»: rozporiadzhennia Kabinetu Ministriv Ukrainy vid 17 bereznia 2011 r. № 2052-r. Ministerstvo finansiv Ukrainy. URL: http://www.minfin.gov.ua/ (data zvernennia: 08.12.2020). 4. Hnatenko Ye. P., Soboleva I. V. Porivniannia finansovoi zvitnosti subiektiv maloho ta mikropidpryiemnytstva Ukrainy ta krain YeS. Molodyi vchenyi. 2017. № 5. S. 537-541. 5. Hohol T. A. Oblikovoanalitychne zabezpechennia upravlinnia pidpryiemstv maloho biznesu : monohrafiia. Chernihiv : Vydavets Lozovyi V.M. 2014. 384 s. 6. Khocha N. V. Perspektyvy vdoskonalennia form finansovoi zvitnosti malykh pidpryiemstv. Biznes Inform. 2018. № 3. S. 259-263. 7. Bezverkhyi K. Poriadok skladannia sproshchenoho finansovoho zvitu subiekta maloho pidpryiemnytstva. Bukhhalterskyi oblik i audyt. 2016. № 11-12. S. 40-50. 8. Harmonizatsiia bukhhalterskoho obliku ta opodatkuvannia na pidpryiemstvakh Ukrainy $v$ konteksti normatyviv YeS : monohrafiia / O. I. Malyshkin, K. V. Bezverkhyi, I. S. Kovova, S. M. Semenova, S. M. Shuliarenko, V. P. Kariev ; za nauk. red. 0. I. Malyshkina. Derzhavnyi universytet infrastruktury ta tekhnolohii. Kyiv : DUIT, 2018. 416 s. 9. Hohol T. A., Niporko N. I. Analiz normatyvno-pravovoi bazy z rehuliuvannia bukhhalterskoho obliku subiektiv maloho biznesu. Ekonomichni nauky. Cer. Oblik i finansy. 2012. Vyp.9(1). S. 208-216. URL: http://nbuv.gov.ua/UJRN/ecnof_2012_9\%281\%29_31 (data zvernennia: 08.12.2020). 10. Drobiazko S. I., Kozyr T. M., Kholod S. B. Oblik ta opodatkuvannia pidpryiemstv maloho biznesu : navch. posib. / za zah. red. P. Y. Atamasa. K. : Tsentr uchbovoi literatury, 2012. 416 s. 11. URL: http://www.ukrstat.gov.ua/ (data zvernennia: 08.12.2020). 12. Directive 2013/34/EU of the European Parliament and of the Council of 26 June 2013 on the annual financial statements, consolidated financial statements and related reports of certain types of undertakings, amending Directive 2006/43/EC of the European Parliament and of the Council and repealing Council Directives 78/660/EEC and 83/349/EEC/. URL: http://eur-lex.europa.eu/ (data zvernennia: 08.12.2020). 13. Kostiuchenko V. M., Kravchuk A. 0. Dosvid Polshchi u yevrokonverhentsii bukhhalterskoho obliku ta audytu. Hlobalni ta natsionalni problemy ekonomiky. Vyp. 20. 2017. S. 971-976. URL: http://global-national.in.ua/archive/202017/197.pdf (data zvernennia: 08.12.2020). 14. Natsionalne polozhennia (standart) bukhhalterskoho obliku 1 «Zahalni vymohy do finansovoi zvitnosti» Zatv. Ministerstvom finansiv Ukrainy vid 7.02.2013 r. № 73. URL: www.mimfin. gov.ua (data zvernennia: 08.12.2020). 15. Polozhennia (standart) bukhhalterskoho obliku 25 


\section{FINANCIAL STATEMENTS FOR SMALL AND MEDIUM-SIZED ENTITIES':} UKRAINE AND WORLD EXPERIENCE

In Ukraine large undertakings and the individual business entities defined by main accounting law have experience of preparing financial reports by IFRS. However accounting reformation declared in The Strategy of IFRS application applies to all business entities including small businesses. Thus it's necessary to define differentiated approaches to the requirements of the preparation of Ukrainian businesses financial reports according to Ukrainian or International standards. In Ukraine, a new businesses classification into micro, small, medium and large businesses was introduced. Micro and small enterprises may independently determine the appropriateness of information disclosure in the financial statements: simplified financial statements or a complete set. Domestic small businesses may also prepare financial statements in accordance with the International Financial Reporting Standard for small and medium-sized entities (IFRS for SMEs). These are companies that are required to apply IFRS in accordance with the law, and those companies that have made such a decision voluntarily. However, in Ukraine small and micro undertakings financial statements are focused primarily on the fiscal services needs. While in European countries a small business reporting is aimed at meeting the information needs of investors, creditors, owners.

According to the EU Directive, micro, small and medium-sized businesses should compile a condensed balance sheet and a condensed income statement, notes. Generally there are no significant differences in the information structure disclosed in the Statement of Financial Position and Income Statement in Ukraine and EU countries. However, the financial statements formation methodology is different. We consider the national legislation should be harmonized with IFRS for small and medium-sized entities. Its not only contains provisions on the financial statements presentation, but also explains important aspects of accounting for small and medium businesses. 
Keywords: small and medium-sized entities; Financial Statements; micro-entity financial reporting; International Financial Reporting Standard (IFRS) for small and medium-sized entities' (SMEs); EU Directives.

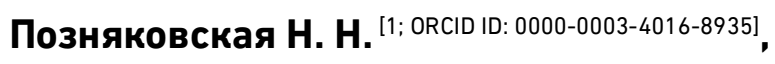
к.э.н., доцент, Демчук М. С. ${ }^{2]}$, бухгалтер

${ }^{1}$ Национальный университет водного хозяйства и природопользования, г. Ровно
${ }^{2}$ Общество с ограниченной ответсвенностью «ЄВРОМОНТАЖЗАХІД», г. Ровно

ФИНАНСОВАЯ ОТЧЕТНОСТЬ МАЛОГО И СРЕДНЕГО БИЗНЕСА: УКРАИНА И МИРОВОЙ ОПЫТ

В статье рассмотрены подходы к финансовой отчетности малых и средних предприятий на мировом и национальном уровнях. Даны рекомендации использования в Украине Международных стандартов финансовой отчетности (МСФО) для малых и средних предприятий. Указаны особенности раскрития финансовой информации в отчетности субъектов малого бизнеса стран ЭС. Для улучшения качественных характеристик финансовой отчетности малых предприятий предлагаются изменения их структуры и содержания.

Ключевые слова: малые предприятия; средние предприятия; финансовая отчетность; упрощенная финансовая отчетность; Международные стандарты финансовой отчетности для малых и средних предприятий; Директивы ЕС. 